УДК 78.071.4:159.952

DOI:

Світлана Теодорович, викладач кафедри музичного мистецтвва Львівського національного університету імені Івана Франка Михайло Ковбасюк, доцент кафедри музикознавства та хорового мистецтвва факультету культури і мистецттв Львівського національного університету імені Івана Франка

\title{
ЕКСТРОСПЕКТИВНА ТА ІНТРОСПЕКТИВНА УВАГА В ПРОФЕСІЙНІЙ ДІЯЛЬНОСТІ ПЕДАГОГА-ХОРМЕЙСТЕРА
}

У статті обтрунтовано важливість знань щьодо екстроспективної та інтроспективної уваги для якісної практичної роботи педагога-хормейстера. Проаналізовано фізіологічні механізми дії екстроспективної уваги, а також розглянуто важливість і актуальність знань і розвитку інтроспективної уваги, яка дозволяє спостерігати і керувати своӥми психічними функціями. Стаття наголошує на важливості подальшого вивчення й запровадження у життя роботи над обома видами уваги як необхідної допомоги у творчій діяльності педагога-хормейстера.

Ключові слова: екстроспективна увага; інтроспективна увага; психічні функцї; диригент-хормейстер. תim. 7.

Svitlana Teodorovych, Lecturer of the Musical Art Department Ivan Franko National University of Lviv Mykhaylo Kovbasyuk, Associate Professor of the Musicology and Choral Art Department, Faculty of Culture and Arts Ivan Franko National University of Lviv

\section{EXTROSPECTIVE AND INTROSPECTIVE ATTENTION IN THE PROFESSIONAL ACTIVITY OF AN EDUCATIONAL CHOIRMASTER}

This article focuses on the importance of deep knowledge about extrospective and introspective attention for quality practical work of an educational choirmaster at conducting lessons as well as with a choir. Types of extrospective attention, which can be volitional, non-volitional and post-volitional, and their parameters are analysed in the article. The article also studies physiological mechanisms of extrospective attention action, which influences creative work of a pedagogue and allows them to concentrate on tasks that need completion. It is of crucial importance for the conductor to be attentive to every nuance and subtlety of the piece that is performed. In addition to that, they need to be attentive to the psychological state, mood and psychological problems of the choir members, as it influences their collective fruitful and determined work. The article also points out that it is advisable for a choirmaster to have a sense of humour to be able to get rid of tension and fatigue of the choir, and also to maintain passion for choir singing with the performers.

The article also analyses the importance and relevance of awareness and cultivation of introspective attention which is so far insufficiently studied. Cultivation of introspective attention enables a person to observe and control their own mental functions such as emotions, feelings and thoughts, which offers great potential for harmonious and creative life. This article provides several techniques and exercises for cultivating inner attention (Musical body, Shikantaza and Vipassana). They broaden the horizons of thinking, help to reach balance and peace of mind, which is of great importance in the emotionally intense creative activity of musicians.

Keywords: extrospective attention; introspective attention; mental functions; a conductor and choirmaster.

П остановка проблеми. В сучасному світі щодня з'являється надзвичайно велика кількість різноманітної інформації, і щоб опанувати іiі, зосередитись на важливому та відсіяти непотрібне, людина повинна вчитися керувати своїми психічними функціями i, зокрема, увагою. Здатність зосередитися на тому, що на даний момент вивчає особа, не відволікаючись на численні подразники оточуючого світу, є досить актуальною у педагогічній діяльності викладача, наставника, який виховує і навчає молоде покоління. Тому глибокі знання про екстроспективну та інтроспективну увагу є запорукою успішної роботи у цій галузі і, власне, в педагогічній діяльності педагога-хормейстера, який взаємодіє із хоровим колективом, повинен налагоджувати 3 його учасниками ділові й приязні стосунки, зосереджувати їхню увагу на виконанні навчальних і творчих завдань.

Аналіз останніх досліджень та публікацій. Проблема розвитку і практики екстроспективної 
уваги розкрита у працях таких психологів і педагогів, як С. Максименко, Л. Дубровська, О. Степанов, М. Фіцула, П. Щербань та інші. Дослідження цієї галузі відбуваються і зараз, але, що стосується інтроспективної уваги, спрямованої на внутрішній світ людини, то тут напрацювань набагато менше і є необмежене поле для подальшого наукового і творчого дослідження.

Метою статті є дослідити й проаналізувати важливість і актуальність екстроспективної та інтроспективної уваги в педагогічній діяльності хорового диригента.

Виклад основного матеріалу дослідження. Проблема уваги має надзвичайно велике значення у практичній діяльності педагога-хормейстера як в роботі 3 хоровим колективом, так і в індивідуальних заняттях зі студентами на уроках диригування. Вміння педагога утримувати i направляти увагу студентів або учасників хору $є$ не менш важливим, ніж вміння володіти власною увагою, вміти лаконічно і точно висловлювати свої зауваження й бути уважним до свого внутрішнього стану рівноваги і спокою.

Увага - це направленість і зосередженість свідомості людини на певних об'єктах при одночасному відволіканні від інших. Розрізняють довільну, мимовільну і постдовільну увагу.

Мимовільна увага виникає спонтанно, без участі волі й бажання людини. Цей вид уваги притаманний як людям, так і тваринам як реакція на будь-який подразник зовнішнього світу. Але що стосується довільної і постдовільної уваги, то вони властиві тільки людям. Довільною увагою особа керує за допомогою вольових зусиль і певного нервового напруження, тоді як постдовільна увага $\epsilon$ природною, без напруження, при цьому людина входить в процес своєї діяльності завдяки інтересу, працюючи цілеспрямовано і легко. Параметрами довільної уваги є концентрація, об'єм, розподіл, тривалість і стійкість.

Концентрація - це ступінь зосередженості уваги на об'єкті;

Об'єм - кількість об'єктів, які можуть бути охоплені увагою одночасно;

Переключення - навмисне перенесення уваги з одного об' єкта на інший;

Розподіл - можливість утримувати у сфері уваги одночасно декілька об'єктів;

Тривалість - час зосередження на певній роботі або завданні;

Стійкість - ступінь зосередженості на об'єкті своєї діяльності без відволікання на інші речі.

“Фізіологічні механізми уваги зосереджені в корі головного мозку, - зазначають київські психологи О. Власова і А. Марушкевич, - але, на відміну від інших процесів безпосереднього пізнання, увага не має спеціального нервового центру, як, наприклад, зоровий, слуховий та інші, що пов'язані з діяльністю певних ділянок кори великих півкуль головного мозку. Фізіологічно увага забезпечується за рахунок явища домінанти як наявності в кожний момент у корі великих півкуль головного мозку ділянки із підвищеною нервовою збудливістю, яка за потужністю нервової активності домінує над іншими частинами кори. Механізм домінанти забезпечують ділянки 3 підвищеною та зниженою збудливістю, взаємопов'язані у своїй діяльності за законом негативної індукції. Коли у певній ділянці кори головного мозку починається сильне збудження, то одночасно, за законом індукції, в інших ділянках, які не пов'язані з виконанням цієї діяльності, виникає гальмування, затухання або навіть повне припинення нервового процесу. В результаті цього одні центри стають збудженими, а інші - загальмованими. В корі головного мозку утворюється домінанта його активності" [2, 332].

Робота диригента-хормейстера пов'язана із постійною концентрацією уваги на якості виконання хорових творів. Він має бути уважним до чистоти інтонування, до дотримання певного темпу виконання, до чіткості й виразності вимови слів літературного тексту, правильного співочого дихання, відсутності форсування звуку, до динамічних і агогічних нюансів тощо. Крім того, уважний керівник повинен помічати психологічний стан учасників творчого процесу - їхню емоційну наснагу або їі відсутність, зосередження на колективній роботі або відволікання від неї, зібраність або розпорошеність їхніх думок. Така направленість уваги називається екстроспективною, тобто направленою на зовнішні об'єкти педагогічного процесу (від латинських слів extra - назовні і spectare - дивитись).

Тривалість уваги як учасників хору, так і самого диригента знижують монотонність, стереотипність виконуваних дій. У цьому випадку доводиться докладати все більше зусиль, щоб досягнути своєї мети, а це, в свою чергу, породжує втому і незацікавленість. Одним із найбільш ефективних засобів організації паузи і зняття втоми є гумор. Чудово, якщо керівник $є$ дотепною і жвавою людиною, що здатна відчути настрій колективу і перенести його увагу на влучний і доречний жарт.

Керування увагою пов'язане також із умінням керувати рухом. Хто не вміє керувати м'язами, той не здатний і до якісної уваги. Здатність зосередитися, сконцентрувати увагу під час співу передбачає активне гальмування усіх сторонніх 


\section{ЕКСТРОСПЕКТИВНА ТА ІНТРОСПЕКТИВНА УВАГА В ПРОФЕСІЙНІЙ ДІЯЛЬНОСТІПЕДАГОГА-ХОРМЕЙСТЕРА}

рухів, завдяки чому виконання набуває виразності, яскравості і правдивості.

В індивідуальній роботі зі студентом на уроках 3 диригування уміння викладача утримувати увагу студента на учбовому завданні $є$ також важливим і необхідним. При їі відсутності робота на уроці гальмується, студент мало корисного для себе виносить із заняття, і результат роботи різко знижується. Для того, щоб цьому запобігти, необхідно повністю заволодіти увагою студента, а для цього доцільно починати роботу “на полі” співрозмовника, із врахуванням перш за все його інтересів, а не власних. Недарма на Сході існував звичай починати розмову із розпитування про здоров'я самого співрозмовника, його батьків і дітей. Відповідаючи на ці запитання, людина активно включається у розмову, і іiї увага поступово переключається на завдання, які перед нею ставлять. Робота стає ефективною - є довіра до педагога, взаємна повага і спільна творча мета.

Про те, наскільки ми буваємо неуважними один до одного, не вміємо вислуховувати й помічати безліч дрібниць, з яких складається світ, наголошував у своїх статтях відомий театральний діяч К. Станіславський. Зокрема, він сказав, що “люди не вміють уважно дивитись і слухати заради пізнання правди життя, заради проникливого і чуйного підходу до людей, заради правдивої художньої творчості. Люди не вміють розрізняти по обличчю, погляду, тембру голосу, в якому стані перебуває їхній співрозмовник, не вміють активно дивитися й бачити складну правду життя, не вміють уважно слухати і посправжньому чути. Якби вони вміли це робити, творчість була б безмежно більш багатою, витонченою і глибокою" $[6,115]$.

Не останню роль у підтримуванні уваги своїх вихованців на високому рівні відіграє особистий інтерес, зацікавленість предметом. Переважно інтерес розглядається психологами як схильність особистості, домінуючий напрямок ії вибірковості. За словами психолога Р. Грановської, “кожний інтерес - це відображення цілісного відношення особистості до світу, що включає не тільки розуміння, а й переживання свого місця у світі, сенсу свого існування і перспектив свого розвитку. Звідси зрозуміло, що глибинні інтереси довготривала структура, яка організовує i підкорює собі епізодичну поведінку людини" $[3,59]$. Для забезпечення стійкої уваги, довготривалої концентрації і впевненого подолання відволікаючих моментів перш за все потрібно подбати про формування у людини відповідного інтересу, тобто необхідно так перебудувати ієрархію цінностей, щоб вона включала і цю задачу у структуру ваших цілей. Якщо це відбудеться, то в подальшому увага буде відсіювати й прибирати все, що не має до проблеми відношення, автоматично, і людина не тільки не докладатиме зусиль, щоб затримати на ній увагу, але, навпаки, їй буде все складніше не помічати все те, що пов'язане із даною метою.

Таким глибинним інтересом, наприклад, може бути зацікавленість студента у набутті професійних навичок і знань 3 даного предмету, 3 яким він пов'язує своє подальше творче життя. Потрібні глибокі і змістовні бесіди на цю і подібні теми, щоб допомогти молодій людині зорієнтуватися і визначитися у своїх уподобаннях, планах на майбутнє і професійних цінностях. Як наслідок, у студента покращиться увага й працездатність на уроці, тому що його діями буде керувати глибокий внутрішній інтерес до навчання.

Окрім екстроспективної уваги, направленої на зовнішній світ, психологи розрізняють ще й інтроспективну увагу (від латинського слова introspecto - дивлюся всередину) - це спостереження власних психічних процесів. Якщо із першим видом уваги ми всі більш-менш обізнані, то про інший вид уваги мало хто знає і ще менше тих, хто практикує.

Увага - це авангард нашої свідомості, а вміння спостерігати за своїми психічними функціями емоціями, почуттями, думками - і керувати ними відкриває величезні можливості для гармонійного і повноцінного творчого життя. Концентрація уваги, зосередження психічної діяльності є джерелом усіх знань людини та основою усіх іiі здібностей. Довільна концентрація уваги являє собою найперший, елементарний акт керування своєю психікою, акт саморегуляції. Без хоча б мінімальної концентрації уваги неможливий жоден вид діяльності. 3 іншого боку, здатність до глибокої концентрації пробуджує в людині різноманітні таланти. Але ця здібність на початкових етапах самовдосконалення залежить від стану психіки і нервової системи. Чим більше людина охоплена емоціями, чим більшим є нервове збудження, тим важче їй на чомусь зосередитись.

Коли людина перебуває у стані чування, іiі нервова система і психіка можуть знаходитися в одному із двох станів: в активному або пасивному. При цьому більшість людей не тільки не може керувати вищеозначеними станами, але й навіть не здатна усвідомлювати їх. Лише зрідка, у виняткових випадках, особа звертає увагу на свій психічний стан і починає розуміти свою безпорадність перед його коливаннями. Але 


\section{ЕКСТРОСПЕКТИВНА ТА ІНТРОСПЕКТИВНА УВАГА В ПРОФЕСІЙНІЙ ДІЯЛЬНОСТІПЕДАГОГА-ХОРМЕЙСТЕРА}

достатньо ситуації змінитись - і людина все забуває. Отже, все повертається на круги своя.

Сучасний білоруський психолог В. Бородкін зазначив, що “причиною безпомічності європейської людини у керуванні своїми станами $€$ жорстка установка направленості психічної активності на зовнішній світ. Така установка сама по собі обумовлює активний стан психіки й нервової системи. Перехід до пасивного стану відбувається лише зрідка й мимовільно. Люди не вміють керувати цим переходом. Перехід у пасивний стан може настати, наприклад, при граничній втомі людини, коли вона падає від знесилля, не хоче нічого бачити і чути, не хоче ні про що думати. Перехід до пасивного стану психіки може відбуватися також після сильного стресу, коли психіка ніби сама включає захисні механізми. Через пасивний стан людина переходить від чування до сну. Тому для більшості людей досить важко залишатися в пасивному психічному стані і при цьому не спати. Але пасивний стан психіки $є$ фундаментом усіх психологічних практик, тому без оволодіння ним неможливі жодні практики концентрації і медитації' $[1,86]$.

Такий стан свідомості, при якому людина може м'яко, ненапружено спостерігати за своїми емоціями, думками, почуттями і одночасно тримати увагу на проблемах і задачах оточуючого світу, називається в містичних традиціях “пробудженням”. Львівські психологи Михайло і Людмила Некрасови підкреслюють, що “у цьому стані включення довільної уваги, яка дозволяє зберігати контроль над різними психічними процесами, може підтримуватися до 18 годин на добу, в той час як у звичайних станах воно дорівнює приблизно 15-20 хвилинам на добу (в інший час люди у своїй життєдіяльності використовують мимовільну механічну увагу, інакше кажучи, сплять). У “пробудженому” стані тривалість справжнього проживання життя збільшується у десятки разів" $[5,262]$. Якщо педагог знаходиться у цьому стані свідомості чи, принаймні, намагається час від часу перебувати у ньому, він кардинально змінює своє бачення світу, ситуацій, людей, усі його рішення приймаються із стану глибокого внутрішнього спокою. Він завжди знаходитиме адекватне до ситуації рішення і надасть слушну пораду своїм учням та колегам, він зберігатиме велику кількість енергії, яка постійно витрачається людьми на непотрібні сварки, роздратування, агресію, образи тощо.

Для розвитку інтроспективної уваги існує безліч прийомів і вправ, але починати бажано із найпростіших. Наприклад, американський психолог Ч. Тарт у своїй праці “Практика уважності у повсякденному житті” пропонує, займаючись звичайними побутовими справами або прогулюючись у парку, невідступно тримати увагу ще й на відчуттях у руках чи ногах. "В ситуаціях особливо насичених емоційно, - пише він, - ви здебільшого не пам'ятаєте про уважність або можете лише невиразно згадати і намагатися відчути свої руки і ноги. Ви (точніше ваш обумовлений розум) може вирішити, що уся ця уважність, відчуття рук і ніг, нічого не вартують у порівнянні з почуттям гніву до негідника, який знаходиться поруч. Іноді найкраще, що ви можете зробити, - це повернутися у теперішній момент через п'ять хвилин після з'ясування стосунків. Тоді ви, принаймні, зможете глибоко зітхнути й дещо розслабитися. Якщо ви взагалі не намагаєтеся бути уважним, може минути кілька днів, перш ніж ви повернетеся у спокійний стан. Якщо ви повернетеся через п'ять хвилин, то, ймовірно, у вас ще залишається можливість вибачитися і не зіпсувати відносини назавжди. Можливо, завдяки подальшому тренуванню у практиках інтроспективної уваги інтервал скоротиться до трьох хвилин, а пізніше і під час вибуху емоцій ви опануєте ситуацію і зможете сказати собі “стоп!”, перш ніж вас накриє наступна емоційно-когнітивна хвиля” [7, 44].

Для практикування уважності Ч. Тарт пропонує також досить цікаву вправу, яку він назвав "Музичне тіло". Суть іiі полягає в тому, щоб, слухаючи музику, відчувати їі спочатку у стопах ніг, потім в колінах, стегнах тощо, тобто уважно “слухати” музику різними частинами тіла, прислухаючись до своїх відчуттів. Увага особи при цьому рівномірно розподіляється між зовнішнім об'єктом (слухання музичного твору) та внутрішнім відчуттям свого тіла, вона $є$ контрольованою і цілеспрямованою, розширює свідомість людини.

Не менш цікавою і корисною є практика буддійської віпасани, основою якої $є$ розвиток уваги до своєї психіки. Буддійський монах Х. Гунаратана у своїй праці "Простими словами про уважність” наголосив, що “уважність - це усвідомлення цього моменту, вона має місце тут і тепер, це спостереження того, що відбувається в даний момент" $[4,48]$. Він запропонував для початку зосередити свою увагу на процесі дихання. Ця практика може виконуватися за будьяких умов і в будь-якій ситуації, тому що дихання, як невід'ємна частина життя, завжди із нами.

Потужною практикою для розвитку як екстроспективної, так і інтроспективної уваги є 
так звана шикантаза (в перекладі $з$ китайської мови означає “безмовне осяяння”), завдяки якій відбувається досягнення стану безмежної відкритості світу, готовності прийняти усі його прояви. При їі виконанні максимально відкриваються “вікна сприйняття” оточуючого і внутрішнього світу, коли практикуючий тримає увагу на тому, що бачить, чує, відчуває. Оволодіваючи цією або іншими техніками інтроспективної уваги, педагог може запропонувати іiї своїм учням, своєму хоровому колективу. Це однозначно підвищить як рівень якості буття людини, яка буде здатна усвідомлено насолоджуватись кожною миттю свого життя, так і рівень якості навчання та професійної творчої діяльності.

Висновки. Поглиблення й розширення знань про екстроспективну та інтроспективну увагу $є$ дуже важливим процесом, адже завдяки володінню і керуванню власною психікою і, власне, такою іiї складовою, як увага, педагог і студент, а також диригент і учасники хорового колективу зможуть досягти у своїй сумісній праці більшої цілеспрямованості, зосередженості у вирішенні поставлених завдань. На репетиціях хору та уроках $з$ диригування завдяки активізації уваги значно підвищується якість роботи, менше часу витрачається на повторення пройденого матеріалу, зростає творчий потенціал педагога i хорового колективу. Безперечно, наукові пошуки щодо оволодіння людиною власною увагою мають великі перспективи на майбутнє, де неминучі нові відкриття, цікаві знахідки, слушні поради, які допоможуть особистості розширити й поглибити свою свідомість.

\section{ЛІТЕРАТУРА}

1. Бородкин В. И. Внутренние рассветы.
Техники психического равновесия. Минск, 2002. $288 \mathrm{c}$.

2. Власова О. І., Марушкевич А. А. Основи психології та педагогіки. Київ, 2011. 333 с.

3. Грановская Р. М. Элементы практической психологи. Ленинград, 1984. $391 \mathrm{c.}$

4. Гунаратана X. Простыми словами о внимательности. Москва, 2005. 192 с.

5. Некрасов М. М., Некрасова Л. С. Витапсихология. Львов, 2011.283 с.

6. Станиславский К. С. Собрание сочинений в 9 т. Москва, 1988. Т. 2.

7. Тарт Ч. Практика внимательности в повседневной жизни. Москва, 1996. 240 с.

\section{REFERENCES}

1. Borodkin, V. I. (2002). Vnutrennie rassvety [Inner dawns. Techniques of psychological balance]. Minsk, 288 p. [in Russian].

2. Vlasova, O. I. \& Marushkevych, A. A. (2011). Osnovy psykholohii ta pedahohiky [Basics of psychology and pedagogics]. Kyiv, 333 p. [in Ukrainian].

3. Granovskaya, R. M. (1984). Elementy prakticheskoi psikholohii [Elements of practical psychology]. Leningrad: Leningrad University publishing house, 391 p. [in Russian].

4. Gunaratana, H. (2005). Prostymi slovami o vnimatelnosti [Mindfulness in Plain English]. Moscow, 192 p. [in Russian].

5. Nekrasov, M. M. \& Nekrasova, L. S. (2011). Vitapsikhologia [Vitapsychology]. Lviv, 283 p. [in Russian].

6. Stanislavskii, K. S. (1988). Sobranie sochineniy $v 9 t$. [Collection of works in 9 volumes]. Moscow, vol. 2. [in Russian].

7. Tart, Ch. (1996). Praktika vnimatelnosti v povsednevnoy zhizni [Living the Mindful Life]. Moscow, 240 p. [in Russian].

Стаття надійшла до редакції 23.09.2019

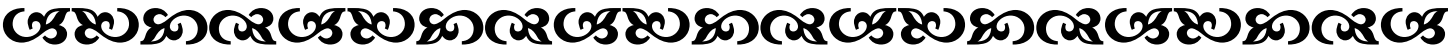

"Толовне в сучасній педагогіиі - ие виховання духовної сторони людини".

Костянтин Уиинський педагог, письменник

“Хто осягає нове, плекаючи старе, той може бути вчителем".

$$
\begin{array}{r}
\text { Конфбучій } \\
\text { давнъожитайський білософб }
\end{array}
$$

"Вище мистеитво, яқим володіє вчитель, - це уміння пробудити радість від творчого вираження й отримання знань".

Альберт Ейнштейн один з найвизначніших бізиків ХХ століття

\section{G5808nc2058080}

